\title{
Effects of Heat Treatment on the Relative Amounts of Cellulose in Nanosilver-Impregnated and Untreated Poplar Wood (Populus alba)
}

\author{
Siavash Bayani ${ }^{1}$ (D), Behzad Bazyar ${ }^{1}$ (D), \\ Seyed Ahmad Mirshokraie ${ }^{2}$ (D), Hamid Reza Taghiyari ${ }^{3}$ (D) \\ ${ }^{1}$ Islamic Azad University (IAU), Tehran, Iran \\ ${ }^{2}$ Payame Noor University (PNU), Tehran, Iran \\ ${ }^{3}$ Shahid Rajaee Teacher Training University (SRTTU), Tehran, Iran
}

\begin{abstract}
The present study investigated the effect of heat treatment on the relative amount of cellulose in untreated and nanosilver-impregnated poplar wood (Populus alba). The impacts on physical and mechanical properties were further studied. Specimens were heated at $145^{\circ} \mathrm{C}$ and $165^{\circ} \mathrm{C}$ in hot air medium. In order to enhance heat transfer to the inner parts of specimens, separate sets of specimens were first impregnated with nanosilver suspension in a pressure vessel. Differential scanning calorimetry (DSC) analyses showed that due to high thermal resistance of cellulose, the cellulose relative volume percent increased along with the increase in thermal temperature and the consequent degradation of other wood polymers (hemicellulose and lignin). High correlation was found between the cellulose relative volume percent versus different physical and mechanical properties. Impregnation with nanosilver increased thermal conductivity in the specimens resulting in an enhanced thermal degradation of hemicellulose and lignin, translated into an increased cellulose relative volume.
\end{abstract}

Keywords: relative amount of cellulose, heat treatment, nanosilver impregnation, Populus alba, thermal degradation. 


\section{INTRODUCTION AND OBJECTIVES}

Heat treatment is a highly effective method to modify wood and forests against some environmental and biological factors, like water and vapor as well as deteriorating fungi (Hill, 2006; Schmidt, 2006; Silveira et al., 2017; Karimi et al., 2017). Moreover, it is environmentally friendly; therefore considered vastly from different perspectives by researchers and industrialists (Hein et al., 2013; Fernandez \& Oliver, 2014; Bastani et al., 2016; Behr et al., 2017; Sandberg et al., 2017), so that low-quality wood species can be improved and used in the industry according to standards (Nandanwar et al. 2013; Gbètoho et al., 2017). Temperatures less than $140^{\circ} \mathrm{C}$ create only quantitative changes in the properties of wood, while temperatures above $300^{\circ} \mathrm{C}$ lead to substantial degradation of wood components. Heat treatment is usually carried out in the temperature range of $185^{\circ} \mathrm{C}$ to $260^{\circ} \mathrm{C}$ (Tiemann, 1915). Heat treatment increases dimensional stability of wood and decreases its hydrophilic properties (Boonstra \& Tjeerdsma, 2006); it also leads to an increase in wood resistance to biological degradation (Tjeerdsma et al., 2000). These improvements facilitated low-density wood species being used in the industry. However, the mechanical strengths decrease depending on the temperature as a result of thermal degradation (Santos, 2000; Taghiyari, 2011).

Changes in the structural polymers of wood are the main source of all the changes mentioned above (Hill, 2006; Taghiyari et al., 2013). These changes are dependent on environmental conditions, temperature, and duration of heat treatment. Higher temperatures cause changes in cell wall polymers. Cellulose tends to have higher resistance to thermal degradation in comparison to hemicellulose and lignin (Tjeerdsma et al., 1998; Tjeerdsma \& Militz, 2005; Esteves et al., 2008). As to the fact that cellulose is considered one of the most important polymers in wood and many mechanical and physical properties of wood are dependent to this polymer, a better knowledge on the beginning temperature for its thermal degradation would provide researchers with a better scope on how to carry out thermal treatment. In this regard, differential scanning calorimetry (DSC) analysis is a fast and direct way to qualitatively evaluate thermal degradation of wood polymers (Reh et al., 1986). Therefore, in the present research project, the relative amount of cellulose after heat treatment at temperature of $165^{\circ} \mathrm{C}$ was analyzed using test DSC.

The correlation between relative amount of cellulose with physical and mechanical properties of poplar wood was further investigated. Due to the low thermal conductivity coefficient of wood (Taghiyari et al., 2013), separate sets of specimens were first impregnated with a nanosilver (NS) suspension to enhance heat transfer to the inner parts of specimens and find out the effects. Moreover, in order to find out to what extent the heattransfer property of NS could affect the low thermal conductivity coefficients of cellulose some carbon-based materials (Majidi, 2016; Tajvidi et al., 2016), separate sets of specimens were prepared to be heated at $145^{\circ} \mathrm{C}$ where only quantitative changes in wood polymers were reported (Tiemann, 1915; Hill, 2006; Taghiyari, 2011). Comparison between different properties of specimens thermally modified at $145^{\circ} \mathrm{C}$ and $165^{\circ} \mathrm{C}$ may reveal the starting temperature of cell wall polymer breakdown. Ultimately, the facilitated heat-transfer in NSimpregnated specimens may present potential application of low temperatures for thermal modification. Lower temperatures for thermal modification would cause lower degrees of polymer breakdown and therefore, it can be recommended to the industry.

\section{MATERIALS AND METHODS}

\subsection{Preparing the specimens}

A poplar (Populus alba) tree was cut from Shafaroud area at the Rezvanshahr town in Gilan Province (Iran) and was converted to small logs to be air-dried for three months. 20 DSC test specimens were prepared with dimensions of $2 \times 2 \times 15 \mathrm{~cm}$ and were randomly divided into five groups of control, heat-treated (HT) at $145^{\circ} \mathrm{C}$ and $165^{\circ} \mathrm{C}$ and nanosilver-impregnated heat-treated (NS-HT). All specimens were again air-dried to the final moisture content of $8 \%$ before any test was carried out on them, because wood has a thermo-hygromechanical behavior and its properties depend on the combined action of temperature, relative humidity, and mechanical load variations (Figueroa et al., 2012).

\subsection{Nanosilver impregnation}

A $400 \mathrm{ppm}$ nanosilver suspension was used to impregnate the specimens. The approximate sizes 
of silver nanoparticles were from $10 \mathrm{~nm}$ to $80 \mathrm{~nm}$. Nanosilver impregnation was performed using an empty-cell method in a sealed tank with a pressure of 2.5 bars for 10 minutes. Once impregnated, all the specimens were randomly positioned along with the untreated specimens in the conditioning room $\left(30^{\circ} \mathrm{C}, 40 \%-45 \%\right.$ relative humidity) for two months. Additional specimens were prepared to be impregnated simultaneously with the specimens for NS-penetration checking. These specimens were cut in half right after the impregnation process to observe if nanosilver suspension penetrated deep in the central part of all specimens.

\subsection{Heat treatment}

Heat treatment was performed in a laboratory oven, model Memmert UFE 700, filled with normal atmospheric air, at 1,712 m elevation above sea level. Untreated and nanosilver-impregnated specimens were randomly arranged on narrow wooden strips to avoid touching the metal trays. For HT-145 and NS-HT-145 specimens, thermal treatment was carried out at $145^{\circ} \mathrm{C}$ for 24 hours. For HT-165 and NS-HT-165 specimens, thermal treatment was carried out at two stages; the first stage was heating at $145^{\circ} \mathrm{C}$ for 24 hours and in the second stage it continued with heating at $165^{\circ} \mathrm{C}$ for four hours.

\subsection{Physical and mechanical properties}

Separate specimens were prepared for Modulus of Rupture Testing Machines (MOR) and Dynamic Testing and Evaluation of Modulus of Elasticity (MOE). The specimen size was $25 \times 25 \times 410 \mathrm{~mm}$ for center-point loading bar, and $25 \times 25 \times 100 \mathrm{~mm}$ for compression strength parallel to the grain. Sampling was randomly done from sapwood and heartwood. Five replicate specimens were prepared for MOR and MOE tests. All specimens were weighted with a digital scale with $0.1 \mathrm{~g}$ precision before and after the thermal treatment to measure weight loss. Physical and mechanical tests were carried out in accordance with ASTM D0143-94 (2007) terms and conditions. Specimens were at a temperature of $20^{\circ} \mathrm{C} \pm 3^{\circ} \mathrm{C}$ at the time of the test. The load was applied through the bearing block to the tangential surface nearest the pith. MOR, MOE, and compression strength parallel to the grain were calculated using Equations 1, 2, and 3, respectively.

$$
M O R=\frac{1.5 F L}{b d^{2}}\left(N / \mathrm{mm}^{2}\right)
$$

$$
M O E=\frac{F L^{3}}{4 b d^{3} D}\left(N / \mathrm{mm}^{2}\right)
$$

$P_{c \|}=\frac{F_{\max }}{A_{o 0}}\left(N / \mathrm{mm}^{2}\right)$

$N$ : Newton; $F$ : maximum force at first failure; $L$ : span length; $b$ : width of specimen; $d$ : thickness of specimen; $D$ : deflection at failure; $F_{\max }$ : maximum force; $A$ : cross-section area of specimen.

Five replicate specimens were prepared for physical properties. The size of the specimens was $20 \times 20 \times 20 \mathrm{~mm}$. Physical properties of water absorption and thickness swelling were measured using Equations 4 and 5.

Water Absorption $=\frac{M_{X}-M_{0}}{M_{0}} \times 100$

$M_{\mathrm{x}}$ : weight (g) at time $x ; M_{0}$ : dry weight $(\mathrm{g})$.

Thickness Swelling $=\frac{T_{X}-T_{0}}{T_{0}} \times 100$

$T x$ : thickness (mm) at time $x$; T0: the initial thickness (mm).

\subsection{Measurement of relative amount of cellulose (DSC analysis)}

DSC analysis was used to determine the relative amounts of cellulose, which can be obtained by comparing the peak heights derived from cellulose burning (Reh et al., 1986). Once heat-treated, the specimens were grounded, and $3 \mathrm{~g}$ of the wood flour was used for each DSC test. In this method, an increase in the peak heights represents a qualitative increase in the relative amount of cellulose in comparison to other wood polymers including hemicellulose and lignin. Device SETARAM DSC 131 was used for the DSC analyses under the following testing conditions: initial temperature of $30^{\circ} \mathrm{C}$, final temperature of $400^{\circ} \mathrm{C}$, and the heating rate was $10^{\circ} \mathrm{C} / \mathrm{min}$. The weight of specimens was 
approximately $3.0 \mathrm{mg}$. Five replicates were performed to get to an average value for each treatment.

\subsection{Statistical Analysis}

Statistical analysis was conducted using SAS software, version 9.2 (Cary, NC USA). Two-way analysis of variance (ANOVA) was performed on the mean data to determine significant differences at the $95 \%$ level of confidence, and then Duncan's multiple range groupings were carried out among different groups. Hierarchical cluster analysis, including dendrograms and Ward methods with squared Euclidean distance intervals, was carried out using SPSS/18, version 18 (IBM; USA). Cluster analysis was performed to find similarities and dissimilarities between treatments based on more than one property simultaneously (Ada, 2013).

The scaled indicator in each cluster analysis shows similarities and differences between treatments; lower scale numbers show more similarities while higher ones show dissimilarities. Fitted-line plots were created in Minitab software, version 16.2.2 (Minitab Inc.; USA).

\section{RESULTS AND DISCUSSION}

Based on the weights before and after the impregnation, nanosilver uptake was calculated to be $0.294 \pm 0.023 \mathrm{~g} / \mathrm{cm}^{3}$. Results of the peak heights of combustion clearly showed that the relative amount of cellulose increased as the temperature of thermal treatment increased (Figure 1). The highest and lowest relative amounts of cellulose were found in NS-HT-165 and in the control treatments, respectively. This indicated that as the temperature for thermal modification increased, the process of hemicellulose degradation aggravated and therefore, the relative amount of cellulose significantly increased. Cellulose peaks at the thermograms showed that the final degradation of cellulose occurred at temperatures ranging from $338^{\circ} \mathrm{C}$ to $350^{\circ} \mathrm{C}$ (Figure 2). In the control specimens, there were considerable amounts of hemicellulose to be burnt before temperature of $300^{\circ} \mathrm{C}$ (Figure 2). However, in nearly all thermally modified specimens, the amount of hemicellulose decreased substantially, showing the effect of thermal modification on degradation of hemicellulose (Figure 2). Heat flow values at temperatures around $260^{\circ} \mathrm{C}$ indicated that control specimens had higher hemicellulose content in comparison to other heat-treated specimens (Figure 2). Moreover, the two NS-impregnated treatments showed a steep slope up to temperature $260^{\circ} \mathrm{C}$, demonstrating easier heat-transfer to all parts of specimens by silver nanoparticles (Li, 2012; Saber et al., 2013; Pethig, 2017), eventually facilitating degradation of hemicellulose in the NS-impregnated specimens.

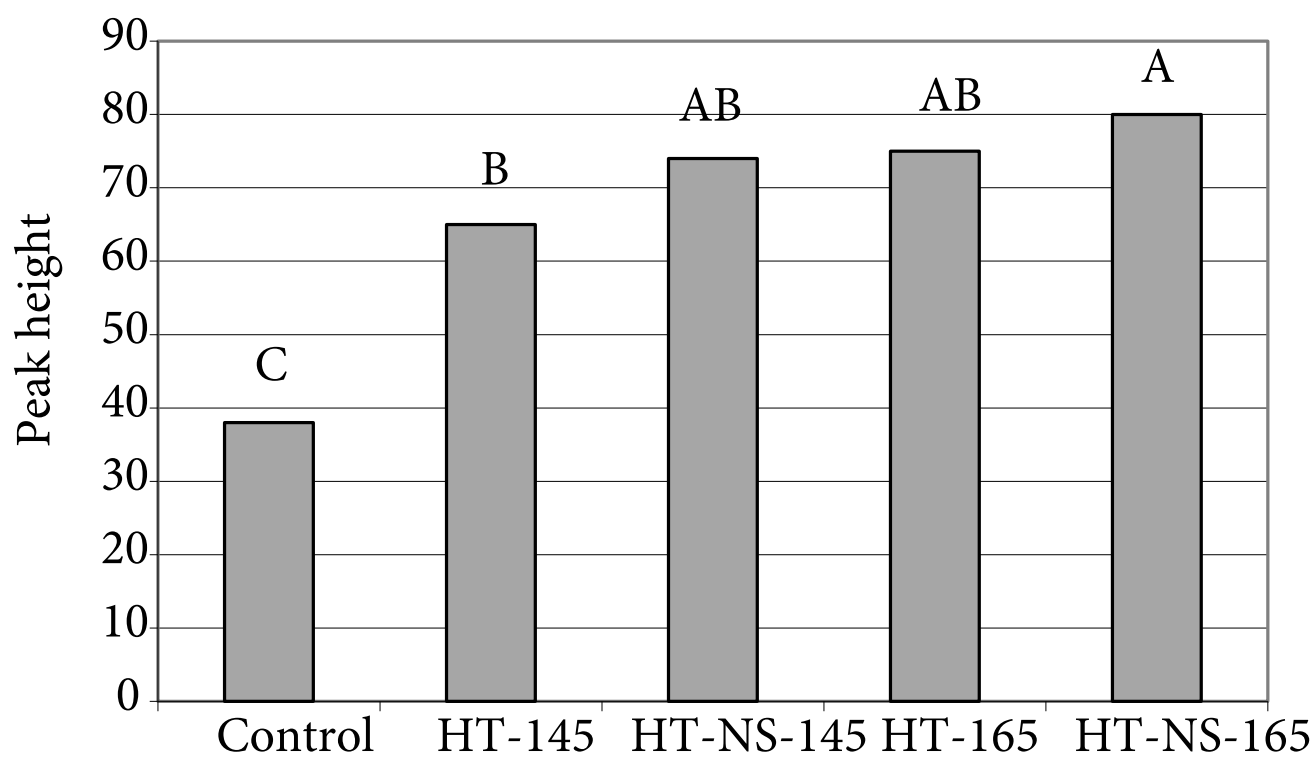

Figure 1. Peak heights showing the relative amount of cellulose obtained from DSC test (letters on each column represent Duncan's multiple range groupings at $95 \%$ level of confidence). 


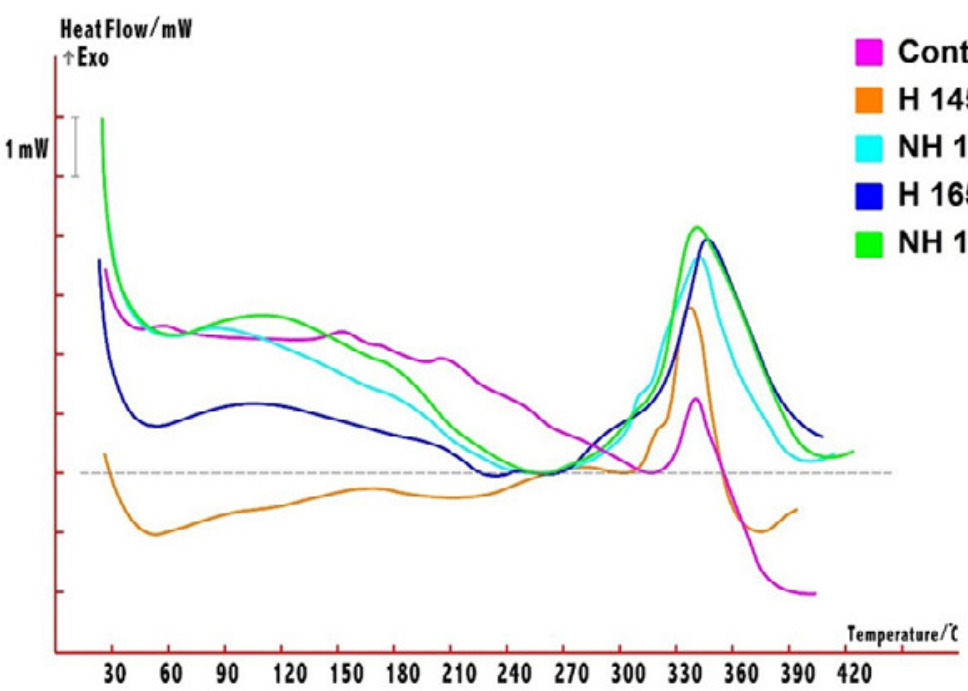

Figure 2. Thermograms of cellulose peak in the control specimens, as well as those thermally modified at $145^{\circ} \mathrm{C}$ and $165^{\circ} \mathrm{C}$, and those first impregnated with nanosilver and then thermally modified at $145^{\circ} \mathrm{C}$ and $165^{\circ} \mathrm{C}$.

Correlation analysis between values of peak height of cellulose versus physical and mechanical properties of the five treatments illustrated high significant R-square values of the physical properties of thickness swelling and water absorption (Figure 3). Correlation analyses of the peak heights of cellulose versus mechanical properties were not as high as those of the physical properties (Figure 4). The higher R-square value with physical properties initially implicated that degradation of hemicellulose polymers had higher impact on TS and WA in comparison to mechanical properties, in thermal modification ranging from $145^{\circ} \mathrm{C}$ to $165^{\circ} \mathrm{C}$. It has also a second implication: it was previously reported that irreversible hydrogen bonding occurs in wood polymers in the course of water movements within the pore system of the cell walls (Borrega \& Kärenlampi, 2010; Taghiyari, 2011; Taghiyari et al., 2013), eventually increasing the stiffness of the wood structure. That is, hemicellulose was greatly degraded in the thermally modified specimens, so lower mechanical properties were expected. However, the process of irreversible hydrogen bonding increased the stiffness of the specimens, compensating to some extent the thermally degraded cell wall components.

In order to find out the effect of impregnation with nanosilver suspension, as well as thermal modification on the overall behavior of different treatments, cluster analysis was conducted based on all peak height values, as well as physical and mechanical properties. Results demonstrated that the control specimens were distinctly clustered compared to the other four thermally modified specimens (Figure 5). This indicated that thermal modification at both $145^{\circ} \mathrm{C}$ and $165^{\circ} \mathrm{C}$ temperatures significantly affect the overall characteristics of poplar wood. HT-145 and HT-NS-145 treatments were closely clustered together and different from treatments at $165^{\circ} \mathrm{C}$. This firstly demonstrated the difference between the two temperatures of thermal modification. Previous studies also reported that wood specimens heated at temperatures about $140^{\circ} \mathrm{C}$ would lose water and volatile extractives (Hill, 2006). However, temperatures above $140^{\circ} \mathrm{C}$ would result in breakdown cell wall polymers, eventually affecting physical and mechanical properties of wood (Hill, 2006). Secondly, it implied that impregnation with nanosilver, and the enhancement in heat-transfer thereof, cannot have significant effect on the overall properties as low temperature of $145^{\circ} \mathrm{C}$. However, HT-NS- 165 treatment was clustered significantly different with the other thermally-modified specimens, demonstrating the significant impact of the enhanced thermal conductivity as a result of impregnation with nanosilver; this can be attributed to the increased production of acetic acid derived from the hemicelluloses, and additional formic acid and methanol that occur at temperatures above $140^{\circ} \mathrm{C}$ (Hill, 2006). 
A

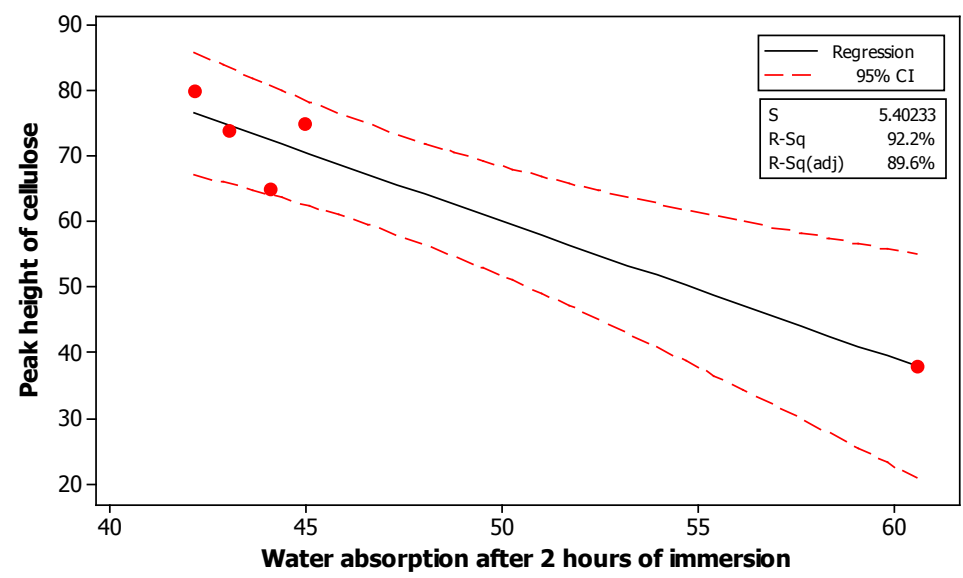

B

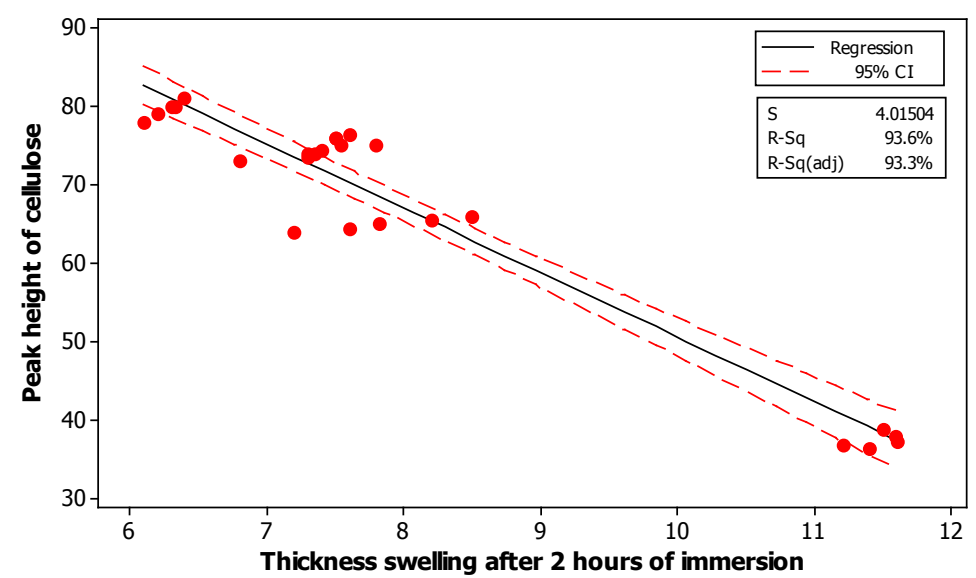

Figure 3. Fitted-line plots of peak height of cellulose versus physical properties of water absorption (A) and thickness swelling (B).

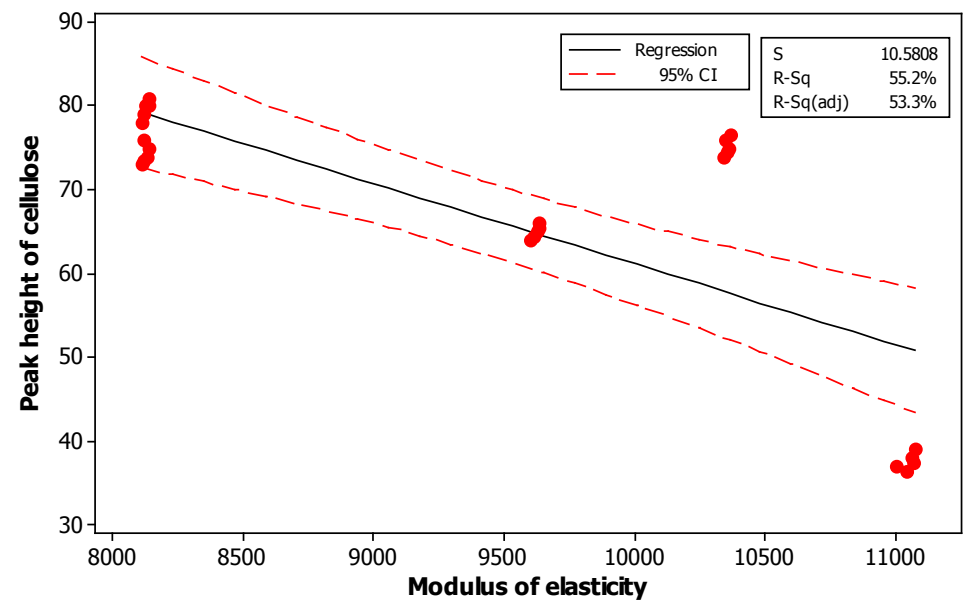

Figure 4. Fitted-line plot of peak height of cellulose versus modulus of elasticity. 


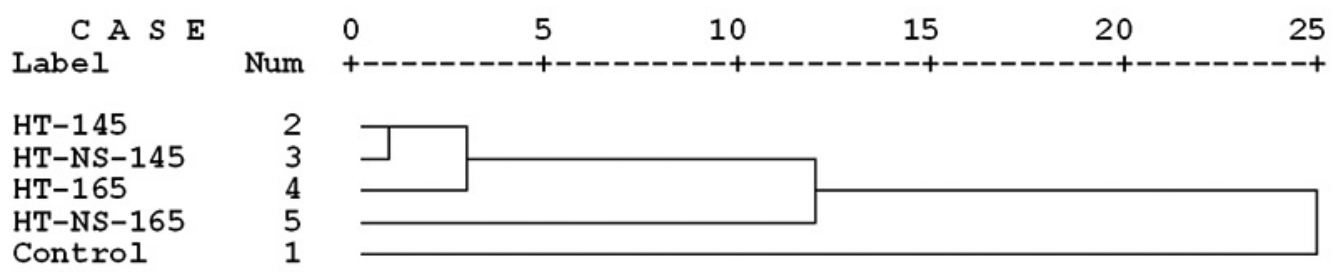

Figure 5. Cluster analysis based on all peak height values as well as physical and mechanical properties.

\section{CONCLUSIONS}

The effects of thermal modification at $145^{\circ} \mathrm{C}$ and $165^{\circ} \mathrm{C}$ on relative amount of cellulose, as well as on physical and mechanical properties, were investigated on poplar wood. Two sets of specimens were further prepared to first be impregnated with silver nanosuspension before thermal modification to investigate the effects of enhanced heat-transfer property on relative amount of cellulose, physical and mechanical properties. Results of the peak height of cellulose showed substantial degradation in hemicellulose in the thermally modified specimens. Degradation of hemicellulose increased as the temperature increased from $145^{\circ} \mathrm{C}$ to $165^{\circ} \mathrm{C}$. Thermograms also showed higher degradation of hemicellulose in NSimpregnated specimens as a result of enhancement in thermal conductivity. High significant correlation values were found between peak height of the relative cellulose content versus physical properties of water absorption and thickness swelling. Lower correlation values between peak height of cellulose versus the mechanical properties were attributed to the irreversible hydrogen bonding in the course of water movement within the pore system of cell wall, resulting in increased stiffness of the cell wall components.

\section{ACKNOWLEDGMENTS}

Dr. Jack Norton (retired, Horticulture \& Forestry Science, Queensland Department of Agriculture, Forestry and Fisheries, Australia); Alexander von Humboldt Stiftung, Germany.

\section{SUBMISSION STATUS}

Received: 23 July, 2016

Accepted: 12 July, 2018

\section{CORRESPONDENCE TO}

\section{Hamid Reza Taghiyari}

Shahid Rajaee Teacher Training University, Sabanloo St., CEP 16788-15811, Tehan, Iran e-mail: htaghiyari@srttu.edu, htaghiyari@yahoo.com

\section{REFERENCES}

Ada R. Cluster analysis and adaptation study for safflower genotypes. Bulgarian Journal of Agricultural Science 2013; 19(1): 103-109.

ASTM D143 - 94. Standard test methods for small clear specimens of timber. ASTM International, 2007. 10.1520/ D0143-94

Bastani A, Adamopoulos S, Militz H. Shear strength of furfurylated, N-methylol melamine and thermally modified wood bonded with three conventional adhesives. Wood Material Science and Engineering 2016; 12(4): 236241. 10.1080/17480272.2016.1164754

Behr G, Bollmus S, Gellerich A, Militz H. Improvement of mechanical properties of thermally modified hardwood through melamine treatment. Wood Material Science \& Engineering 2017; 13(5): 262-270. 10.1080/17480272.2017.1313313

Borrega M, Kärenlampi PP. Hygroscopicity of heat-treated Norway spruce (Picea abies) wood. European Journal of Wood and Wood Products 2010; 68(2): 233-235. 10.1007/ s00107-0090371-8

Boonstra MJ, Tjeerdsma B. Chemical analysis of heat treated softwoods. Holz als Roh-und Werkstoff 2006; 64(3), 204-211. 10.1007/s00107-005-0078-4

Esteves B, Graça J, Pereira H. Extractive composition and summative chemical analysis of thermally treated eucalypt wood. Holzforschung 2008; 62(3): 344-351. 10.1515/HF.2008.057

Fernandez-Puratich H, Oliver-Villanueva JV. Quantification of biomass and energetic value of young natural regenerated stands of Quercus ilex under Mediterranean conditions. Bosque 2014; 35(1): 65-74. 10.4067/S0717-92002014000100007 
Figueroa M, Bustos C, Dechent P, Reyes L, Cloutier A, Giuliano M. Analysis of rheological and thermo-hygromechanical behaviour of stress-laminated timber bridge deck in variable environmental conditions. Maderas: Ciencia y Tecnologia 2012; 14(3): 303-319.

Gbètoho AJ, Aoudji AKN, Roxburgh L, Ganglo JC. Assessing the suitability of pioneer species for secondary forest restoration in Benin in the context of global climate change. Bois et Forets des Tropiques 2017; 332(2): 43-55.

Hein PRG, Silva JRM, Brancheriau L. Correlations among microfibril angle, density, modulus of elasticity, modulus of rupture and shrinkage in 6-year-old Eucalyptus urophylla $\times$ E. grandis. Maderas: Ciencia y Tecnologia 2013; 15(2):171-182. 10.4067/S0718-221X2013005000014

Hill C. Wood modification: chemical, thermal and other processes. Chichester: Wiley; 2006.

Karimi M, Daryaei MG, Torkaman J, Oladi R, Ghanbary MAT, Bari E et al. Natural decomposition of hornbeam wood decayed by the white rot fungus Trametes versicolor. Anais da Academia Brasileira de Ciências 2017; 89(4): 2647-2655. 10.1590/0001-3765201720160714

Li D. Nanostructuring materials towards conventionally unachievable combination of desired properties. Journal of Nanomaterials \& Molecular Nanotechnology 2012; 1(1). 10.4172/2324-8777.1000e102

Majidi R. Electronic properties of graphyne nanotubes filled with small fullerenes: a density functional theory study. Journal of Computational Electronics 2016; 15(4): 1263-1268. 10.1007/s10825-016-0925-Z

Nandanwar A, Naidu MV, Pandey CN. Development of test methods for wooden furniture joints. Wood Material Science and Engineering 2013; 8(3): 188-197. $10.1080 / 17480272.2013 .814712$

Pethig R. Review: where is dielectrophoresis (DEP) going? Journal of Electrochemical Society 2017; 164(5): B3049-B3055. 10.1149/2.0071705jes

Reh U, Kraepelin G, Lamprecht I. Use of differential scanning calorimetry for structural analysis of fungally degraded wood. Applied and Environmental Microbiology 1986; 52(5): 1101-1106.

Saber R, Shakoori Z, Sarkar S, Tavoosidana G, Kharrazi S, Gill P. Spectroscopic and microscopic analyses of rodshaped gold nanoparticles interacting with single-stranded
DNA oligonucleotides. IET Nanobiotechnology 2013; 7(2): 42-49. 10.1049/iet-nbt.2012.0009

Sandberg D, Kutnar A, Mantanis G. Wood modification technologies: a review. iForest 2017; 10(6): 895-908. 10.3832/ifor2380-010

Santos JA. Mechanical behaviour of Eucalyptus wood modified by heat. Wood Science and Technology 2000; 34(1): 39-43. 10.1007/s002260050006

Schmidt O. Wood and tree fungi: biology, damage, protection, and use. Heidelberg: Springer-Verlag; 2006.

Silveira AG, Santini EJ, Kulczynski ST, Trevisan R, Wastowski A, Gatto DA. Tannic extract potential as natural wood preservative of Acacia mearnsii. Anais da Academia Brasileira de Ciências 2017; 89: 3031-3038. 10.1590/0001-3765201720170485

Taghiyari HR. Study on the effect of nano-silver impregnation on mechanical properties of heat-treated Populus nigra. Wood Science and Technology 2011; 45(2): 399-404. 10.1007/s00226-010-0343-5

Taghiyari HR, Enayati A, Gholamiyan H. Effects of nano-silver impregnation on brittleness, physical and mechanical properties of heat-treated hardwood. Wood Science and Technology 2013; 47(3): 467-480. 10.1007/ s00226-012-0506-7

Tajvidi M, Gardner DJ, Bousfield DW. Cellulose nanomaterials as binders: laminate and particulate systems. Journal of Renewable Materials 2016; 4(5): 365376. 10.7569/JRM.2016.634103

Tiemann HD. The effect of different methods of drying on the strength of wood. Lumber World Review 1915; 28(7): 19-20.

Tjeerdsma BF, Boonstra M, Pizzi A, Tekely P, Militz H. Characterization of thermal modified wood: molecular reasons for wood performance improvement. Holz Rohund Werkstoff 1998; 56: 149-153. 10.1007/s001070050287

Tjeerdsma BF, Militz H. Chemical changes in hydrothermal treated wood: FTIR analysis of combined hydrothermal and dry heat-treated wood. Holz als Roh-und Werkstoff 2005; 63(2): 102-111. 10.1007/s00107-004-0532-8

Tjeerdsma BF, Stevens M, Militz H. Durability aspects of (hydro) thermal treated wood. In: Proceedings of the International Research Group on Wood Preservation; 2000; Kona, Hawaii. Stockholm: IRG-WP; 2000. 